Practically, the Fellows of the College have a remedy in their own hands wherewith to redress their grievances, and by having recourse to its adoption at the next two or three July elections they have the power of introducing into the Counci of the College any amount and kind of.reform which they may conceivo most conducive to the gencral and permanent welfare of that institution.

I am, Sir, your obedient servant,

Southampton, Nov. 10th, 1868. JOHN WIBLIST

\section{THE ROYAL MEDICAL COLLEGE.} To the Editor of THE LANCET.

SIR,-CThe letters which have recently appeared in your columns about the education at Epsom College, contain very thinly veiled imputations upon the efficiency of those who are charged with the arrangement and carrying out of the studies. In plain English, the failure of certain pupils at the "preliminary examination" is thrown back upon the masters, and an investigation is demanded to set the matter to rights. What view the head master and his coadjutors may take of this proposal it is no business of mine to inquire; but as one who has known the school from its foundation, and who has had ample opportunities of forming a judgwent as to the plan of education which is pursued in it, I think that $I$ am entitled to be heard. When, moreover, I add that I an not a medical man, and that no one connected with the College will know anything about the contents of this letter until they see it in print, I shall have said enough to convince you that $I$ am at least an unbiased witness.

Of Dr. Thornton, and his ability as a teacher of youth, it seems superfiuous to speak. The school is simply his own creation, the outgrowth of untiring work and energy. In the hands of a less gifted man it would scarcely have attained a respectable mediocrity; for when the Council give their minds to favour dunces and idlers, and frown down all suggestion of the cane or expulsion, it certainly does become allttle difficult to secure anything like satisfactory discipline or progress. But though the head master has been denied privileges which are commonly accorded to ushers in a private school, it cannot be seriously gainsaid that the pupils have attained a high state of proficiency in their various studies, and that, so far as the test of experience has as yet been applied, their success after removal from the school has fully justified their sound and careful training.

But Natural Science is not properly taught-so your correspondent grumbles. No, of course it is not; and without a laboratory, and other appliances, I do not understand how the feat is to be accomplished. But I know that, immediately after his appointment, Dr. Thornton petitioned for the necessary means for carrying on this branch of education; and I further know that the scientific bias of his mind, joined to varied and extensive study, would make him a singularly happy instructor. Up to the period of my last visit to Epsom, in the spring of this year, his frequent appeals had becn in vain. But has nothing been done? Yes. A few years ago a gentleman was appointed by the Conncil-contrary to the byelaw which gives appointments of this sort to the head-master - to lecture on Natural Science once a week. $\mathrm{He}$ is not a tutor, be it observed, but merely a lecturer, and therefore it is easy to guess what progress an idle or listless boy would make under such supervision.

This ought to be a sufficient answer to your correspondent ; but I must add a word more. Able as I am to testify to the anxiety with which Dr. Thornton has for many years been looking forward to the day when his suggestion as to a laboratory and apparatus should be favourably received by the Council as the necessary condition of successful teaching, and convinced as I am that he would be the last man to desire to see Natural Science omitted from the scheme of education at the College, I would beg to suggest a question or two to your correspondents, and any one else who may be inclined to answer them. Does the Council aid or hamper the headmaster in his work? Do they attend to his reasonable suggestions as regards discipline, improvement of the holidays, and so on? And, lastly, do they offer adequate salaries to their masters?

Nov, 4th, 1868 I am, Sir, your obedient servant,

Cantab.

\section{THE POOR-LAW MEDICAL SERVICE AND} CANDIDATES FOR PARLIAMENT.

\section{To the Editor of THE LANCET.}

Silk, - The enclosed form of letter has been forwarded to every member of the Poor-law Medical Officers' Association, with an earnest request that he would at once transmit it to any candidate for a seat in Parliament for the county or borough in which he may reside.

Although our members are to be found in every county in England and Wales, I have, on the part of the Council, to request that you will kindly insert it in THE LANCET of this week, so that Poor.law medical officers who have not joined us may adopt a similar form of letter in their application to candidates. I I

\section{3, Dean-street, solo, Nov. 11th, 1868 . President of the Associat}

\section{November th, 1868}

Sir,-The grievances of the Poor-law medical officers of Fngland and Wales, upwards of 3000 in number, and having charge of more than a million and a half of poor sick persons annually, being universally acknowledged, I am requested by the Council of the Poor-law Medical Officers'Association to inquire of you whether, in the event of your being returned to varliament, -

1. You will endeavour to amend the constitution of the Poor-law Board by securing the appointment thereto of medical and other members, competent to devise and carry out uniform and efficient system of medical relief to the sick poor?

2 . Whether you will support any well-devised measure that may be brought forward in Parliament to obtain justice for the medical officers, and adequate remuneration for their services?

Requesting the favour of an early reply,

- Esq.

I am, Sir, yours obediently,

\section{MEDICAL REPRESENTATION IN PARLIAMENT.}

A MeFring of the medical profession was held in the Moles. worth Lecture Hall, Dublin, on Tuesday, to discuss the above subject. It was most numerously attended.

Dr. Lyons having been voted to the chair, it was proposed by Dr. R. McDonnell, F.R.S., and seconded by Dr. Hynes"That in the opinion of this meeting it is in the highest degree desirable, on public as well as professional grounds, that a medical man of eminence, as representative of the medical profession, should be returned to the new Parliament."

Professor Hayden moved, and Dr. Ashe, of Warrenpoint seconded the next resolution-"That this meeting has learned with great regret that the Council of the Trish Medical Association, a body for years professing its anxiety to establish professional representation in Parliament, has declined to act on the present occasion, when the opportunity presents itself of promoting the return of a medical candidate."

It was next moved by Dr. O'Meara, of Carlow, and seconded by Dr. Cruise-" That this meeting is of opinion that it is most desirable to take immediate steps to secure the return of a representative of the medical profession in Ireland."

Sir D. Corrigan was then called on by the Chairman, and made a lengthened speech, detailing his opinions on nearly every question of medical politics.

It was then moved by Dr. Fitzpatrick, and seconded by Dr. Byrne- "That this meeting, having heard the exposition of Sir D. Corrigan's views, pledges itself to use its best exertions to secure his return."

Dr. Mapother next proposed and Dr. Davys seconded a resolution to the effect "That this meeting is of opinion that the best course to obtain superannuation for medical officers is by the introduction of a special Bill for that purpose, as suggested by Sir D. Corrigan in his address to the profession."

The last resolution was as follows- "That the cordial thanks of this meeting be given to the country medical practitioners who have so well supported the cause of the representation of our profession in Parliament by their liberal subscriptions."

Dr. Hynes, Vice-President of the Irish Medical Association, having been called to the second chair, the proceedings terminated. 